\title{
The Practice of Social Return On Investment
}

Recent decades have shown steady growth in the quantity of literature on social sustainable issues ((Carter \& Rogers, 2008) (Krause, Vachon, \& Klassen, 2009) (Yawar \& Seuring, 2017)). Yawar and Seuring study concluded that the environmental dimension received more attention than the social dimensions of sustainable development. Procurement, this powerful tool plays an important role in driving the sustainable procurement plan (Preuss, 2009). Environmental and social regulations have been adopted in many nations to promote sustainability in public procurement (Andrecka, 2017). However, a major flaw of public procurement relates to ecological, social, and economic dimensions (Elkington, 1998). Social return on investment (SROI) is a device utilized to develop social sustainability and designed to measure and understand the future social, economic, environmental, and financial impact of an organization. Also, SROI can be used to improve managerial processes to be more efficient and effective. This can be practiced by any organization to evaluate the impact on stakeholders and identifying ways to improve performances (Bellucci, Nitti, Franchi, Testi, \& Bagnoli, 2019).

Ronald McDonald House Charities (RMHC) Italy apply the SROI methodology to their activities. Before implementing, they devised a strategy based on their goals: mapping all of the activities involved in the management of RMHC in Italy, identifying and calculating appropriate financial proxies, and identifying suitable indicators for estimating outputs and outcomes (Bellucci, Nitti, Franchi, Testi, \& Bagnoli, 2019). This SROI approach describes these events using an input-output-outcome system that depends on robust dialog with stakeholders (Manetti, Bellucci, \& Bagnoli, 2015). SROI theory of change (the relationship between input-output-outcome) (Klemelä, 2016) attempts to describe the changes by building a story of the change in qualitative and quantitative among a project's main stakeholders. The last step in calculating the SROI index is by identifying any potential displacement, deadweight, attribution and drop-off effects from the value result for each outcome. The outcome has many advantages and some complications that needs to be fixed. The author of (Wilson \& Bull, 2013) is also a team manager of the Joint Commissioning and Performance Management Team was involved with a social enterprise, Wooden Canal Boat Society, in supporting their journey in conducting an SROI. In the SROI process, it involves several processes in the impact assessment map: identifying what social value means to the stakeholders, understanding that to create value it needs a set of activities, and comparing the financial value of social change to the financial cost that producing these changes (Wilson \& Bull, 2013).

According to (Suyanto, Pratono, Zurbrügg, \& Marciano, 2017) social return on investment for the Green and Clean Campaign in Surabaya, there were advantages and disadvantages. That campaign was starting to motivate the neighborhood groups to practice waste segregation and composting resulting, in Surabaya City reduced the volume of waste from 1,500 to 1,150 tons per day. Based on interviews and group discussions, it encouraged households to venture into producing a small-scale garden from planting vegetables to herbal plants. This program helped the communities build a stronger connection inside and out of households, reducing the cost of vegetables, fruits, visits to the medical clinic, and even gained income from recycling. However, this study needs to obtain more resources and conduct a longitudinal surveys in the future. 


\section{Bibliography}

Yawar, S., \& Seuring, S. (2017). "Management of social issues in supply chains: a literature review exploring social issues, actions and performance outcomes". Journal of Business Ethics, Vol. 141 No. 3, pp. 621-643.

Carter, C., \& Rogers, D. (2008). "A framework of sustainable supply chain management: moving toward new theory". International Journal of Physical Distribution and Logistics Management, Vol. 38 No. 5, pp. 360-387.

Krause, D., Vachon, S., \& Klassen, R. (2009). "Special forum on sustainable supply chain management: introduction and reflections on the role of purchasing management". Journal of Supply Chain Management, Vol. 45 No. 4, pp. 18-25.

Preuss, L. (2009). "Addressing sustainable development through public procurement: the case of local government". Supply Chain Management: An International Journal, Vol. 14 No. 3, pp. 213-223.

Andrecka, M. (2017). "Corporate social responsibility and sustainability in Danish public procurement". European Procurement and Public Private Partnership Law Review, Vol. 12 No. 3, pp. 333-345.

Elkington, J. (1998). Cannibals with Forks: The Triple Bottom Line of 21st Century Business. John Wiley and Sons, London.

Suyanto, Pratono, A. H., Zurbrügg, C., \& Marciano, D. (2017). "SOCIAL RETURN ON INVESTMENT FOR COMMUNITY-BASED ENTERPRISE IN SURABAYA CITY". The Hong Kong Journal of Social Work, Vol. 51 No.1/2.

Vluggen, R., Kuijpers, R., Semeijn, J., \& Gelderman, C. J. (2020). "Social return on investment in the public sector". Journal of Public Procurement, Vol. 20 No. 3,, pp. 235-264.

Bellucci, M., Nitti, C., Franchi, S., Testi, E., \& Bagnoli, L. (2019). "Accounting for social return on investment (SROI) : The costs and benefits of family-centred care by the Ronald McDonald House Charities". Social Enterprise Journal, Vol. 15 No. 1, pp. 46-75.

Manetti, G., Bellucci, M., \& Bagnoli, L. (2015). "Investing in volunteering: Measuring social returns of volunteer recruitment, training and management". OLUNTAS: International Journal of Voluntary and Nonprofit Organizations, Vol. 26 No. 5, pp. 2104-2129.

Klemelä, J. (2016). "Licence to operate: Social return on investment as a multidimensional discursive means of legitimating organisational action". Social Enterprise Journal, Vol. 12 No. 3, pp. 387-408.

Wilson, D., \& Bull, M. F. (2013). SROI in practice: the Wooden Canal Boat Society. Social Enterprise Journal, Vol. 9 No. 3, pp. 315-325. 